\title{
KÖTŐTECHNOLÓGIÁK ALKALMAZHATÓSÁGI VIZSGÁLATA GYÉMÁNTSZEGMENSES FÚRÓKORONÁKHOZ
}

\section{APPLICABILITY INVESTIGATION OF JOINING TECHNOLOGIES FOR DIAMOND CORE BITS}

\author{
Kenéz Attila Zsolt,, ${ }^{1,2}$ Bagyinszki Gyula ${ }^{3}$ \\ ${ }^{1}$ Hilti Szerszám Kft., Kecskemét, Magyarország, attila.kenez@hilti.com \\ ${ }^{2}$ Óbudai Egyetem, Anyagtudományok és Technológiák Doktori Iskola, Budapest, Magyarország, \\ kenez.attila@phd.uni-obuda.hu \\ ${ }^{3}$ Óbudai Egyetem, Bánki Donát Gépész és Biztonságtechnikai Mérnöki Kar, Budapest, Magyarország, \\ bagyinszki.gyula@bgk.uni-obuda.hu
}

\begin{abstract}
For the joining of two metallic components of different material quality, different methods of welding or soldering techniques are used. In this case, these two material qualities are given by the segments containing diamond particles, and thin-walled steel tube. In our previous paper we analysed welded joints with two different kinds of laser sources. In this paper we extend the previous investigations with the analysis of capacitor discharge welded and flame soldered samples. We examine the microstructure of the joints and record the chemical element maps to determine if alloying was formed. Joints are also subjected to fracture and hardness testing. This investigation shows that the applied joining technology meets the increased technical requirements because the joining zone must bear high mechanical and significant thermal loads during usage.

Keywords: joining technologies, welding, soldering, diamond segment, material investigation.

\section{Összefoglalás}

Két különböző anyagminőségű fémes alkatrész tartós összekötéséhez általában a hegesztés vagy a forrasztás különböző eljárásait használják. Jelen esetben a két eltérő anyagminőséget a gyémántszemcséket tartalmazó szegmensek és az acélcső képviseli. Előző cikkünkben kétféle lézerforrással hegesztett kötéseket elemeztünk. Jelen cikkünkben kiegészítjük a korábbi vizsgálatokat kondenzátorkisüléses hegesztéssel és lángforrasztással készült minták értékelésével. Vizsgáljuk a kötési zónák szövetszerkezetét, elemtérképeket is készítünk, hogy történik-e átötvöződés. A kötéseket töréstesztnek és keménységvizsgálatnak vetjük alá. Ezek a vizsgálatok azt is megmutatják, hogy a kötések megfelelnek-e a fokozott műszaki követelményeknek, hiszen a kötési zónát használat közben nagy mechanikai és jelentős hőterhelések is érik.
\end{abstract}

Kulcsszavak: kötési technológiák, hegesztés, forrasztás, gyémántszegmens, anyagvizsgálat.

\section{Bevezetés}

Napjainkban a leggyakrabban alkalmazott kötéstechnológiák gyémántszegmensek rögzítéséhez a hegesztés vagy a forrasztás különböző eljárásai. A szegmensek összetételének és geometriájának fejlődése megköveteli a kötéstechnológiák fejlesztését is. A jelenleg alkalmazott lézerhegesztés mellett keressük azt a kötési eljárást, ami technológia és költség oldalról is megfelel az elvárásoknak. Az újonnan alkalmazott kötéstechnológiáknak is meg kell felelniük a környezetvédelmi és a műszaki követelményeknek egyaránt. 
A gyémántszegmenses fúrókoronák termékfejlesztési projektjei már abba az irányba mutatnak [1], hogy a technológiafejlesztéssel is szükséges foglalkoznunk. Ezért vizsgáltuk meg egy korábbi cikkünkben [2], hogy különböző lézerforrások milyen hatással vannak a kötési zónára, és ezért vizsgálunk új kötési technológiákat is.

Jelen cikkünkben kiegészítjük a korábbi vizsgálatokat kondenzátorkisüléses hegesztéssel és lángforrasztással készült minták értékelésével. Első lépésként azt vizsgáljuk, hogy az adott technológia milyen hatással van a termékre, és később foglalkozunk majd az optimalizálás lehetőségével.

\section{Technológiai kísérletek}

\subsection{A kísérletek folyamata}

A termékportfólióból kiválasztottuk az $\emptyset 102$ mm-es terméket (1. ábra) - melynek hegesztéséhez a szériagyártásban a szilárdtest- lézerforrást használjuk -, és legyártottuk kondenzátorkisüléses hegesztéssel, továbbá lángforrasztással is. Ez utóbbi technológia azért került szóba, mert az egyedileg értékesített szegmenseket a vevő forrasztja fel magának. A kiválasztott termék 8 szegmenst tartalmaz, melyek a cső homlokfelületén egyenlő távolságban vannak elosztva.

A lézerhegesztést vettük alapul - mint a szériatermékekhez használt technológiát -, és ehhez hasonlítottuk a kondenzátorkisüléses hegesztést és a lángforrasztást. Azt vizsgáltuk, hogy a különböző kötőeljárások milyen hatással vannak a kötési zónára és a szegmensre.

\subsubsection{Lézerhegesztési kísérlet}

A kísérletet egy Trumpf TruDisk 4002 (max. 4,0 kW teljesítményü, 1,03 $\mu \mathrm{m}$ hullámhosszúságú) lézerforrással végeztük el.

A lézerforrás egy teljesen automatizált géppel van kapcsolatban, egy rezgőadagolóból kerülnek

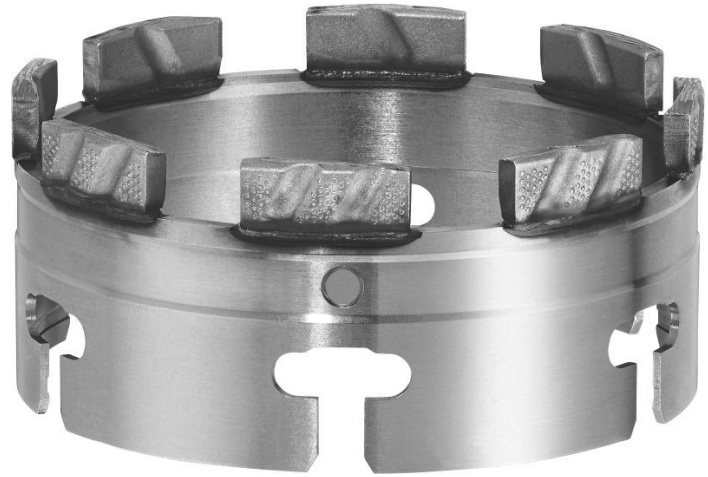

1. ábra. Ø102 mm-es fúrókorona katalógusképe be a szegmensek a belső, kétállásos adagoló-pozicionáló egységbe, ami a robot által behelyezett cső homlokfelületéhez illeszti a szegmenset. A gép konstrukciója olyan, hogy a lézerfej mozog hegesztés közben, és egyszerre egy szegmens hegesztése történik. A hegesztési idő alatt a szegmensadagoló-egység előkészíti a következő szegmenst a pozicionáló másik állásába, ezzel csökkentve a mellékidőket és biztosítva a következő szegmens gyors pozícióba kerülését.

\subsubsection{Kondenzátorkisüléses hegesztési kísérlet}

A kísérletet egy függőleges elrendezésű géppel végeztük el, 198/160 V impulzusfeszültséggel és 3,2 bar pneumatikus szorítónyomással.

A gép kialakításából adódóan egyszerre egy szegmens hegesztése történik a csőre. A szegmens egy automatikus adagolószerkezettel kerül az elektródába. A csőhöz egy másik elektróda csatlakozik. Összeérintik a komponenseket, majd ráadják a szorítónyomást. Ezután a kondenzátorban tárolt elektromos energiát az elektródák révén a hegesztési helyre vezetik, majd végbemegy a hegesztés.

\subsubsection{Láng-keményforrasztási kísérlet}

A kísérletet kézi eljárással végeztük. A folyamatot azzal kezdtük, hogy a cső homlokfelületét és a szegmens alját megcsiszoltuk P80-as csiszolópapírral, majd ezeket a felületeket bekentük folyasztószerrel. A szegmenset a csőre illesztettük és lánggal melegítettük a csövet. Távolról indultunk és lassan közelítettünk a szegmenshez, elkerülve a túlhevítést. Amikor megjelent egy vékony sárga „csík” - jelezve a megfelelő hőmérsékletet -, forraszanyagot adagoltunk a kötési zónába és lánggal eloszlattuk. A forraszanyag megszilárdulása után sűrített levegővel lehütöttük a kötés környezetét.

\subsection{A kísérletek során alkalmazott kötő- technológiák}

\subsubsection{Lézerhegesztés}

Az indukált emisszióra „kényszerített” anyag minőségétől függő hullámhosszúságú monokromatikus, koherens lézersugarat optikai elemek segítségével a hegesztés helyére fókuszolják. A kis átmérőjű fókuszfoltban igen nagy teljesítménysűrüség érhető el, és megfelelő abszorpció révén az elektromágneses sugárzás hővé alakul a hegesztendő anyagokban. A fellépő hőmérséklet keskeny sávban megolvasztja az összeillesztett 
munkadarabok határát, és az elhaladó sugárzás mögött keskeny hőhatásövezetü, csekély torzulást okozó varrat képződik [3, 77. o].

A teljesítménysürüség a varrat mélység/szélesség arányán, ill. a kötés alakján keresztül befolyásolja a lehűlési sebességet és az ömledék létidejét. Ez nemcsak a varrat szövetszerkezetét határozza meg, hanem azokat az időtartamokat is, amelyek alatt a kötészóna egy-egy kritikus hőmérséklet-tartományon keresztüljut.

A nagy teljesítménysűrűség eredményeképpen gyorsan létrejövő ömledéket fajlagosan nagy határfelület választja el a szilárd anyagtól, ill. a megömlesztett térfogat kicsi a munkadarab össztérfogatához képest, így az ömledék igen gyorsan hül. A hevítés és a lehülés sebességének ilyen megnövekedése jelentősen befolyásolja a fázisátalakulást szenvedő anyag mennyiségét.

A nagy teljesítményű lézersugár - szemben az elektronsugárral - vákuum nélkül is nagy energiasűrüséget biztosító, térben és időben koherens, kis divergenciájú monokromatikus fénynyaláb, mellyel bármilyen optikailag elérhető felület megmunkálható. Fő hátránya az energiaelnyelés (abszorpció) jelentős felületállapot-függése és az alacsony hatásfok.

Eltérő minőségű fémes anyagok (ötvözetek) lézeres hegeszthetőségének két alapvető feltétele van:

- A két fém képes legyen egyidejüleg megömleni és közös ömledéket képezni. Ez a feltétel nehezen teljesül, ha a két fém olvadáspontja messze esik egymástól, vagy a hővezető képességük nagyon különbözik. Ezért, ha szükséges, a lézersugarat aszimmetrikusan irányítják a nehezebben megömlő fém felé;

- A két fém metallurgiailag kompatibilis legyen, azaz ne keletkezzenek megengedhetetlen intermetallikus fázisok, átmeneti vegyületformák a hegesztési folyamat során. Ha két ötvözet kötéséről van szó, még hozzávetőlegesen sem lehet következtetést levonni az egyensúlyi diagramokból, hanem előzetes kísérleteket kell végezni [4, 15-16. o].

Lézeres hegesztési eljárásoknál nincs szükség sem a cső, sem a szegmens felületének hegesztés előtti (előkészítő) megmunkálására és általában nincs szükség hozaganyagra sem a kötés kialakításához.

\subsubsection{Kondenzátorkisüléses hegesztés}

A kondenzátor impulzushegesztéskor a hegesztéshez szükséges energiát a korábban feltöltött kondenzátorok egy tirisztoron keresztül a mun- kadarab speciális transzformátoraihoz vezetik. A töltési idő 0,5-2 másodperc közötti, a hegesztési idő 3-10 ms között van [5]. A kondenzátorkisütéses hegesztés különleges tulajdonságait a következő folyamatjellemzők írják le: meredek áramerősség-növekedés, rövid hegesztési idő, nagy hegesztőáramok, alacsony hőbevitel, alacsony hálózati terhelés, magas reprodukálhatóság, továbbá különböző anyagvastagságú munkadarabok, különböző anyagminőségek (pl. acél, sárgaréz), rozsdamentes acélok, vékony lemezek, galvanikus bevonatokkal ellátott munkadarabok hegeszthetősége.

A hegesztés egyik legnagyobb előnye az áram meredek növekedése és a hő gyors bevezetése a hegesztési zónába. Ez a hegesztési hőmérséklet gyors elérését eredményezi, még mielőtt a környező anyag felmelegszik.

A kondenzátor impulzushegesztési eljárásánál nincs szükség hozaganyagra a kötés kialakításához, azonban szükséges a cső vagy a szegmens felületének hegesztés előtti (előkészítő) megmunkálása. Ennek két változata lehet:

- a cső homlokfelületét rovátkolják/recézik, és a szegmens felülete sík marad;

- a cső homlokfelülete sík marad, és a szegmens

felületébe készítenek keresztirányú hornyot.

\subsubsection{Láng-keményforrasztás}

A forrasztást a forrasztandó anyagok olvadáspontjánál kisebb olvadáspontú, olvadék állapotba hozott forraszanyaggal végzik. Forrasztáskor a kölcsönös diffúzió révén alakul ki a kapcsolat, melynek feltétele, hogy a forraszanyag és az egyesítendő anyagok szilárd állapotban oldják egymást. Ha nem teljesül a kölcsönös oldódás feltétele, akkor a megolvasztott forraszanyag a ragasztáshoz hasonló adhéziós jellegü kötést hoz létre.

A forraszanyagok olvadási hőmérséklete, illetve az ennek megfelelő forrasztási hőmérséklet, továbbá a kötés várható szilárdságának mértéke alapján megkülönböztetnek:

- lágyforrasztást, $450{ }^{\circ} \mathrm{C}$-nál kisebb hőmérsékletekkel és max. $50 \mathrm{MPa}$ kötési szilárdsággal;

- keményforrasztást, $450{ }^{\circ} \mathrm{C}$-nál nagyobb (rendszerint $900{ }^{\circ} \mathrm{C}$-nál kisebb) hőmérsékletekkel és max. 300 MPa kötési szilárdsággal [3, 136. o].

A keményforrasztás viszonylag nagy szilárdságot ad, és a kötés nagyobb üzemi hőmérsékleten is alkalmazható. Nem szükséges sem a cső, sem a szegmens felületének forrasztás előtti (előkészítő) megmunkálása, de folyasztószer alkalmazása indokolt a folyamat elején. 


\subsection{A kísérletekhez felhasznált anyagok}

\subsubsection{Szegmens}

A szegmensek gyártása porkohászati úton történik, a porok összekeverése után egy berendezés rétegről rétegre építi fel a szegmenst, és ekkor kerülnek bele a meghatározott méretű gyémántszemcsék is. A rétegzési folyamat teljesen szabályozott, szabadon variálható a rétegek vastagsága és száma.

A gyémántszegmensek 2 fő zónából állnak, az egyik a vágásért felelős „vágózóna”, a másik a hegesztéshez szükséges „neutrál” vagy semleges zóna. Ezután beállítják a szegmens sűrüségét, mely befolyásolja a hegesztést, a vágás sebességét, a vágótest kopását az alkalmazás során.

A szegmensek neutrál zónájának kémiai összetétele: Astaloy-Mo $=99,8 \%$, grafitpor $=0,2 \%$, cinksztearát $=0,5 \%$, míg a szegmensek anyagának sürüsége $7870 \mathrm{~kg} / \mathrm{m}^{3}$.

\subsubsection{Acélcső}

A szegmenseket egy vékony falú acélcsőre rögzítjük, mely hidegen húzott E235+C $(1,0308)$ anyagminőségű, EN 10305-1 szabvány szerinti [6], $2 \pm 0,15 \mathrm{~mm}$ falvastagságú.

A cső kémiai összetétele: $\mathrm{C} \leq 0,17 \%, \mathrm{Si} \leq 0,35 \%$, $\mathrm{Mn} \leq 1,2 \%, \mathrm{P} \leq 0,025 \%, \mathrm{~S} \leq 0,025 \%$.

\subsubsection{Forraszanyag}

A láng-keményforrasztási kísérlethez Fontargen A324 jelü $(\mathrm{Ag}=49 \%, \mathrm{Zn}=23 \%, \mathrm{Cu}=16 \%, \mathrm{Mn}=7,5 \%$, $\mathrm{Ni}=4,5 \%$ ) EN ISO 3677 szabványnak megfelelő [7] forraszanyagot és Easy-floTM 100 Flux Paste folyasztószert használtunk. A forraszanyaghoz ajánlott forrasztási munkahőmérséklet $690^{\circ} \mathrm{C}$.

\section{Kötési zónák vizsgálatai}

Hegesztett kötések és/vagy varratok roncsolásos vizsgálatára többnyire az alapanyag vizsgálatára használt eljárásokat alkalmazzák. A roncsolásmentes vizsgálatok során a vizsgálandó munkadarab nem károsodik.

A szóba jöhető roncsolásmentes vizsgálati eljárások:

- optikai vizsgálat;

- geometriai vizsgálat;

- minimum-próba;

- radiológiai vizsgálat (röntgenvizsgálat, radioaktív izotópos vizsgálat);

- mágnesezhető porral végzett vizsgálat;

- folyadékpenetrációs vizsgálat;
- ultrahangvizsgálat;

- örvényáramos vizsgálat;

- CT-vizsgálat.

A szóba jöhető roncsolásos vizsgálati eljárások:

- törésteszt (statikus hajlítás);

- keménységvizsgálat;

- energiadiszperzív spektroszkópia;

- makrocsiszolat-vizsgálat;

- optikai fénymikroszkópos vizsgálat;

- pásztázó elektronmikroszkópos vizsgálat;

- szakítóvizsgálat;

- hajlítóvizsgálat (korona- és gyökoldali);

- ütővizsgálat;

- fárasztóvizsgálat.

A fúrókoronáknak meg kell felelniük a rájuk vonatkozó műszaki előírásoknak. Először a szériagyártásban alkalmazott roncsolásmentes (optikai, geometriai vizsgálat, Minimum-próba) és roncsolásos vizsgálatokat (törésteszt) végeztük el, majd a hegesztett kötést és a hőhatásövezetet vizsgáltuk (makrocsiszolat-, pásztázó elektronmikroszkópos, keménységvizsgálat).

\section{Vizsgálati eredmények}

\subsection{Roncsolásmentes vizsgálatok eredményei}

\subsubsection{Optikai vizsgálat}

A vizsgálat célja: varratkép ellenőrzése fényképes hibakatalógusban meghatározott követelmények alapján.

A vizsgálat eredménye:

- a lézerhegesztett mintánál nem látható hiba a varratban;

- a kondenzátorkisülésesen hegesztett minta nagymértékü képlékeny alakváltozásból eredő kisajtolódást mutat a minta külső oldalain;

- a forrasztott minta egyenletes forraszanyagvastagságot mutat.

\subsubsection{Geometriai vizsgálat (szegmenskiállás)}

A vizsgálat célja: meghatározni a szegmenskiállás átlagos értékét, melynek 0,9 < átlag < 1,4 mm között kell lennie.

Alkalmazott mérőeszköz: digitális kijelzésű mérőóra.

A vizsgálat eredménye:

- lézerhegesztett minta: átlag = 1,29 mm;

-kondenzátorkisüléssel hegesztett minta: átlag = 1,16 mm;

- forrasztott minta: átlag = 0,923 mm.

Az elvégzett mérések alapján megállapítható, hogy mindhárom minta esetében az átlagérték türésen belül van. 


\subsubsection{Geometriai vizsgálat (szegmensdőlés)}

A vizsgálat célja: meghatározni a szegmensdőlés átlagos értékét (a szegmensek párhuzamossága a cső külső palástjával), melynek $\pm 0,2 \mathrm{~mm}$ között kell lennie.

Alkalmazott mérőeszköz: digitális kijelzésű mérőóra.

A vizsgálat eredménye:

- lézerhegesztett minta: átlag = -0,018 mm;

- kondenzátorkisüléssel hegesztett minta: átlag $=-0,225 \mathrm{~mm}$;

- forrasztott minta: átlag = 0,001.

$\mathrm{Az}$ elvégzett mérések alapján megállapítható, hogy a lézerhegesztett és keményforrasztott minta esetében az átlagérték türésen belül van, míg a kondenzátorkisüléssel hegesztett minta átlagértéke kisebb, mint az alsó tűréshatár. Ez következhet a hegesztés során fellépő nagymértékű képlékeny alakváltozásból.

\subsubsection{Geometriai vizsgálat (szegmenscsavarodás)}

A vizsgálat célja: meghatározni a szegmenscsavarodás átlagos értékét (a szegmens rádiusza mennyire követi a cső rádiuszát), mely max. 0,4 mm lehet.

Alkalmazott mérőeszköz: digitális kijelzésű mérőóra.

A vizsgálat eredménye:

- lézerhegesztett minta: átlag = -0,07 mm;

-kondenzátorkisüléssel hegesztett minta: átlag $=-0,225 \mathrm{~mm}$;

- forrasztott minta: átlag = -0,032 mm.

Az elvégzett mérések alapján megállapítható, hogy mindhárom minta esetében az átlagérték türésen belül van.

\subsubsection{Geometriai vizsgálat (radiális ütés a szegmensen)}

A vizsgálat célja: meghatározni a radiális ütés értékét a szegmensen (a fúrókoronát körbeforgatva a szegmensek felületén mért radiális ütés), mely max. 0,55 mm lehet.

Alkalmazott mérőeszköz: digitális kijelzésű mérőóra.

A vizsgálat eredménye:

- lézerhegesztett minta: átlag = 0,35 mm;

- kondenzátorkisüléssel hegesztett minta: átlag = 0,515 mm;

- forrasztott minta: átlag = 0,104 mm.

Az elvégzett mérések alapján megállapítható, hogy mindhárom minta esetében az átlagérték türésen belül van.

\subsubsection{Minimum-próba}

A vizsgálat célja: az előírt minimális határértékkel, azaz 9 Nm nyomatékkal kell minden szegmenst megterhelni. A szegmensre a formájához illeszkedő betétet helyeznek, ami nyomatékhatárolóval ellátott nyomatékkulcshoz csatlakozik. A hegesztett kötés minőségét tesztelve, az előírt minimum forgatónyomatékkal terhelik a szegmenseket.

Nem volt sérülés a kötési zónákban egyik minta esetében sem, vagyis a nyomatékminimumot minden szegmens károsodás (törés) nélkül viselte el.

\subsection{Roncsolásos vizsgálatok eredményei}

\subsubsection{Törésteszt}

A vizsgálat célja: meghatározni a szegmens letöréséhez szükséges nyomaték átlagos értékét, melynek min. 9 Nm-nek kell lennie. A szegmensre a formájához illeszkedő betétet helyeznek, ami nyomatékhatárolóval ellátott nyomatékkulcshoz csatlakozik. A kulcs nullázása után a szegmenst kifelé irányuló mozdulattal letörik, és leolvassák a kijelzett értéket.

A vizsgálat eredménye:

- lézerhegesztett minta: átlag = 16,4 Nm;

-kondenzátorkisüléssel hegesztett minta: átlag = 24,7 Nm;

- forrasztott minta: átlag = 13,3 Nm.

Az elvégzett törésteszt alapján a minták megfelelnek a rajzi előírásoknak, mindhárom minta esetében a minimális határérték feletti teherbírásértékeket mértünk.

\subsubsection{Mikroszkópi vizsgálatok}

A három minta vizsgálatai alapján megállapítható, hogy:

- a vizsgált lézerhegesztett minta metszetében gázbuborékok és repedésszerű mintázatok is megfigyelhetők, főleg a szegmens felőli oldalon (2. ábra);

- a vizsgált kondenzátorkisüléses hegesztéssel készített minta metszetében az ellenállás hegesztésre jellemző nagymértékű képlékeny alakváltozást elszenvedett zónák figyelhetők meg mindkét elemben (3. ábra);

- különösen jelentős ez az alakváltozás - a megolvadt, illetve kilágyult fém kisajtolódása - a minta külső oldalain (3. ábra);

- a kötés környezetében - a nagymértékű képlékeny alakváltozás következtében - jelentősen torzult a szemcseszerkezet mind a felhegesztett szegmens, mind a csőalapanyag esetében (4. ábra); 


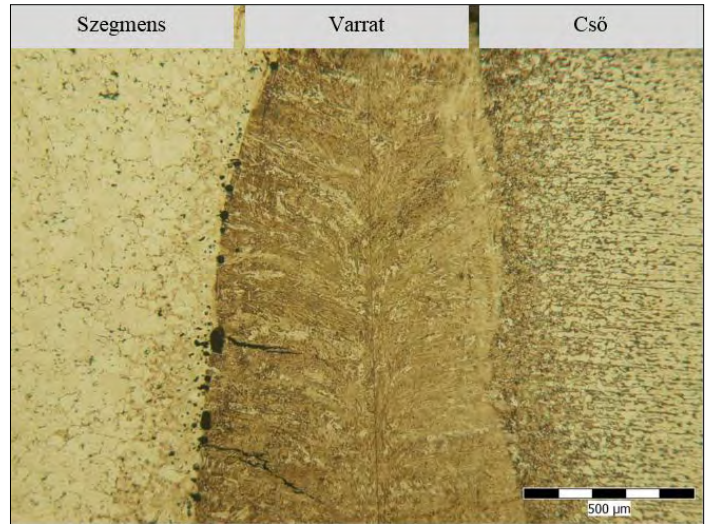

2. ábra. Optikai mikroszkópos felvétel a lézerhegesztett varratról

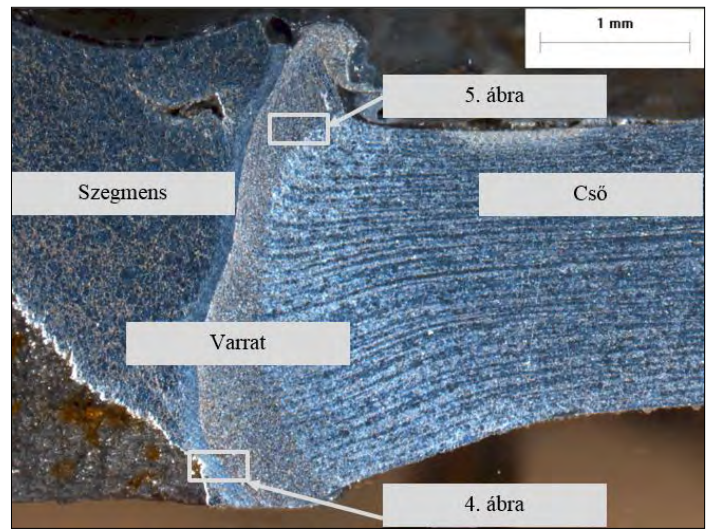

3. ábra. Sztereomikroszkópos felvétel a kondenzátorkisüléssel hegesztett varratról

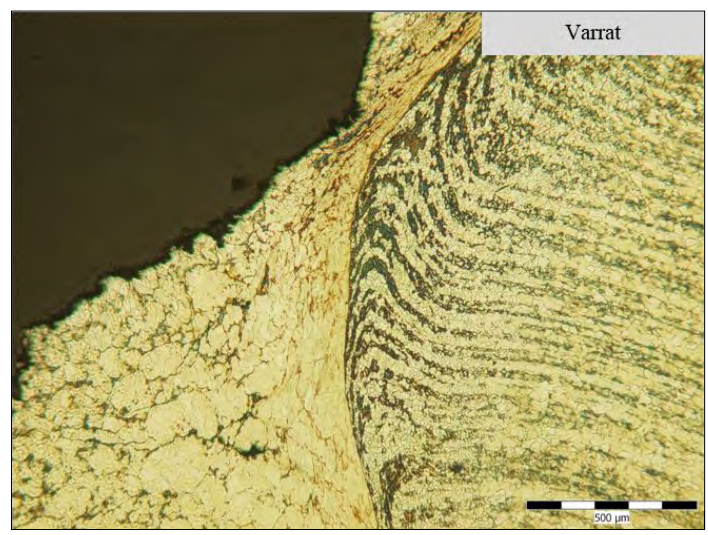

4. ábra. Optikai mikroszkópos felvétel a kondenzátorkisüléssel hegesztett varratról

- a kisajtolódás következtében a képlékenyen alakváltozott anyagok jellegzetes soros, szálas morfológiát mutatnak, amely különösen jól megfigyelhető a cső anyagának érintett zónájában (5. ábra);

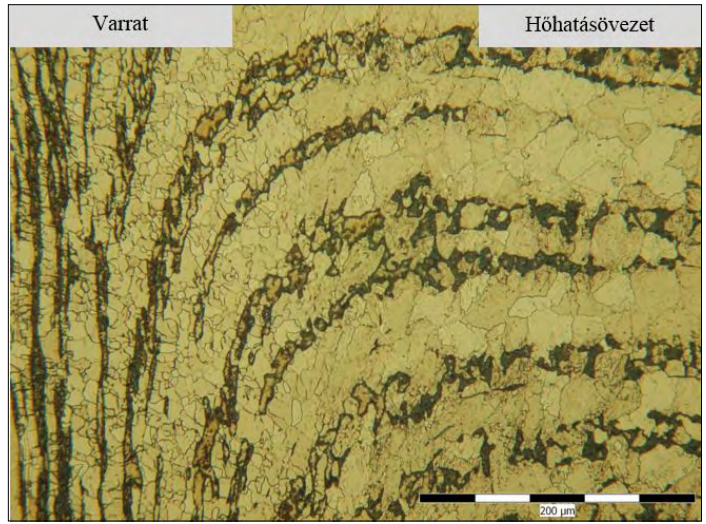

5. ábra. Optikai mikroszkópos felvétel a kondenzátorkisüléssel hegesztett varratról

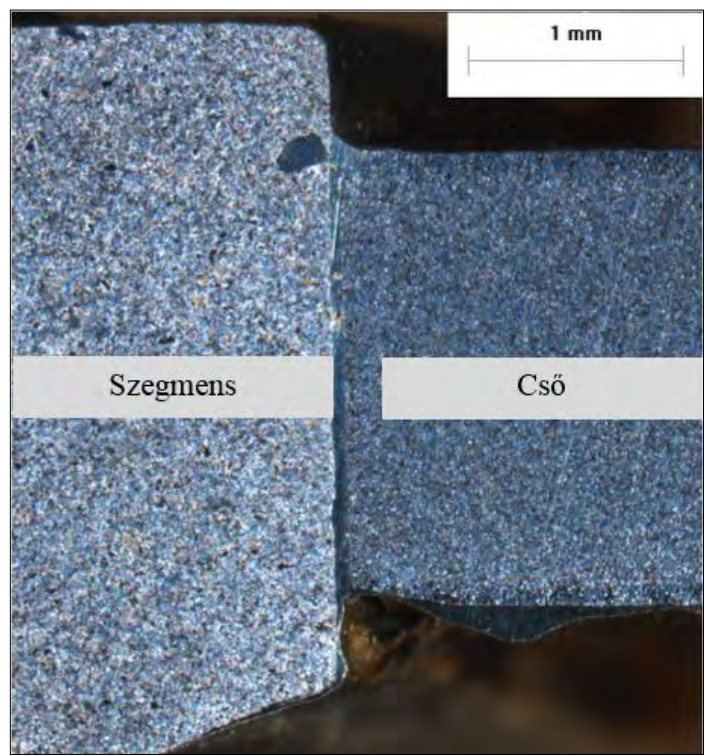

6. ábra. Sztereomikroszkópos felvétel a forrasztott mintáról

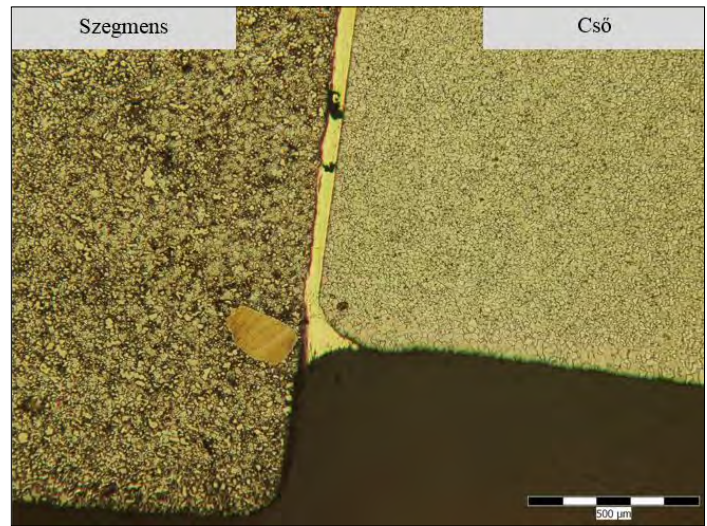

7. ábra. Optikai mikroszkópos felvétel a forrasztott mintáról 


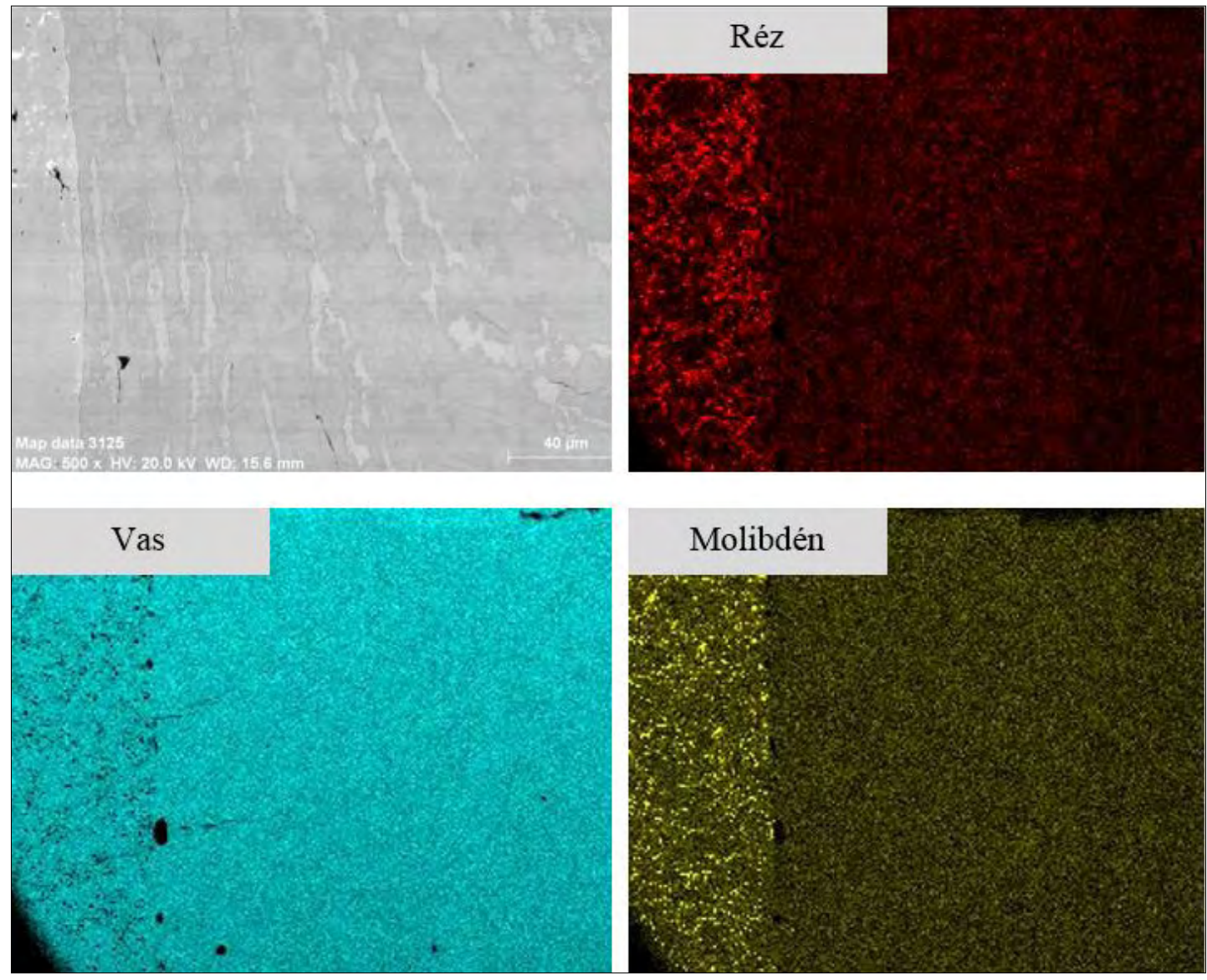

8. ábra. Elemtérkép a lézerhegesztett varratról

- a varratban hibára utaló zárvány, repedés vagy össze nem olvadt felület nem figyelhető meg;

- a vizsgált lángforrasztott minta jó réskitöltést, egyenletes forraszanyag-vastagságot mutat (átlagosan $200 \mu \mathrm{m})$ (6. ábra);

- a forrasztás lényegében hibamentes, csak apróbb, zárványnak tűnő képi elemek figyelhetők meg a metszetén (7. ábra).

\subsubsection{Pásztázó elektronmikroszkópos vizsgá- lat}

A három minta vizsgálatai alapján megállapítható, hogy:

- a szilárdtest lézerrel hegesztett varratban gázbuborékok és mikrorepedésszerü képi elemek is észlelhetők;

- a varrat-elemtérképeken a fő ötvözők tekintetében (Mo, Mn, Fe, Cu, C) nem figyelhető meg számottevő különbség az egyes zónák között, így

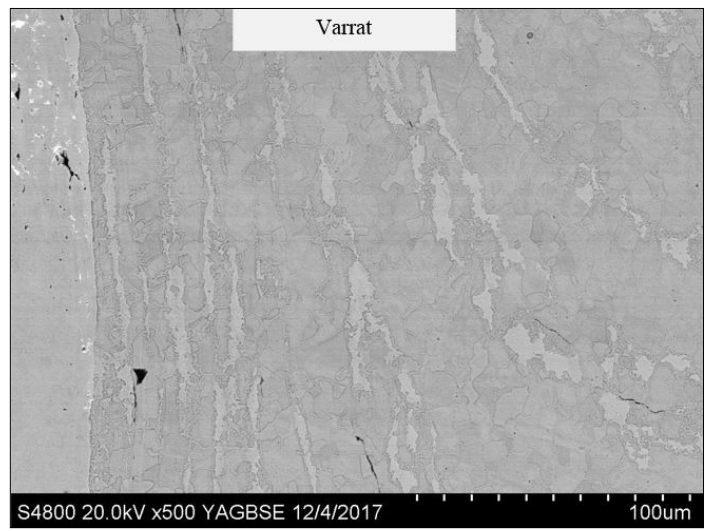

9. ábra. Pásztázó elektronmikroszkópos felvétel a kondenzátorkisüléssel hegesztett varratról

megállapítható, hogy nem történt ötvöződúsulás és beötvöződés a varratban (8. ábra);

- a kondenzátorkisülésesen hegesztett varratban (9. ábra) mikrorepedésszerű képi elemek észlelhetők; 


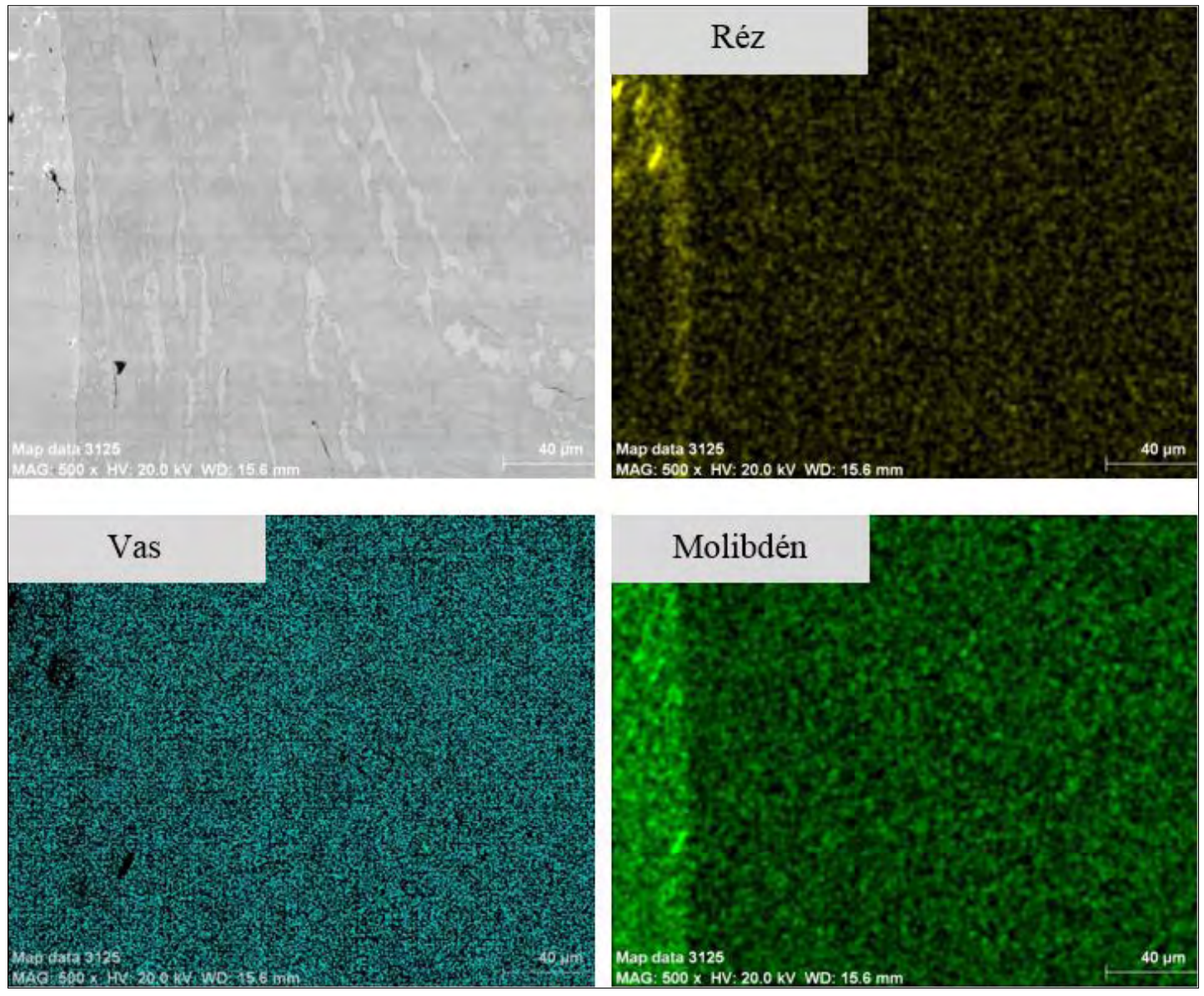

10. ábra. Elemtérkép a kondenzátorkisüléssel hegesztett varratról

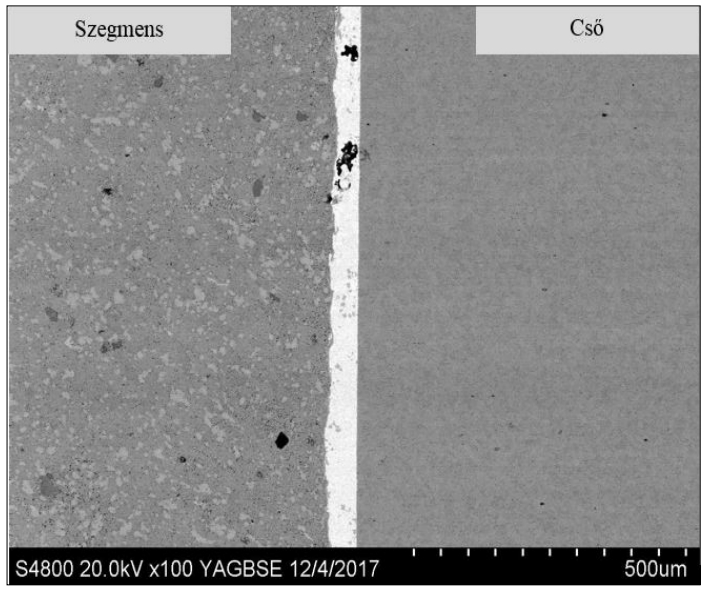

11. ábra. Pásztázó elektronmikroszkópos felvétel a forrasztott mintáról
- a varrat-elemtérképeken a fő ötvözők tekintetében (Mo, Mn, Fe, $\mathrm{Cu}, \mathrm{C}$ ) nem figyelhető meg számottevő különbség az egyes zónák között, így megállapítható, hogy nem történt ötvöződúsulás és beötvöződés a varratban (10. ábra);

- a forrasztott minta vizsgálata alapján megállapítható, hogy csak apróbb, zárványnak tűnő képi elemek jelennek meg (11. ábra);

- sem a neutrális zónában, sem a csőalapanyagban szövetszerkezeti változás nem figyelhető meg; - az EDX-spektrumból, melyet a 11. ábrán látható területről gyüjtöttünk (12. ábra), kiválasztottuk a komponensek (szegmens, cső és forraszanyag) összetételére jellemző elemeket. Megállapítható, hogy nem történt beötvöződés.

\subsubsection{Keménységvizsgálat}

A hegesztett varratok és kötések ellenőrzésére a Vickers-vizsgálatot alkalmazzák. Igen vékony 


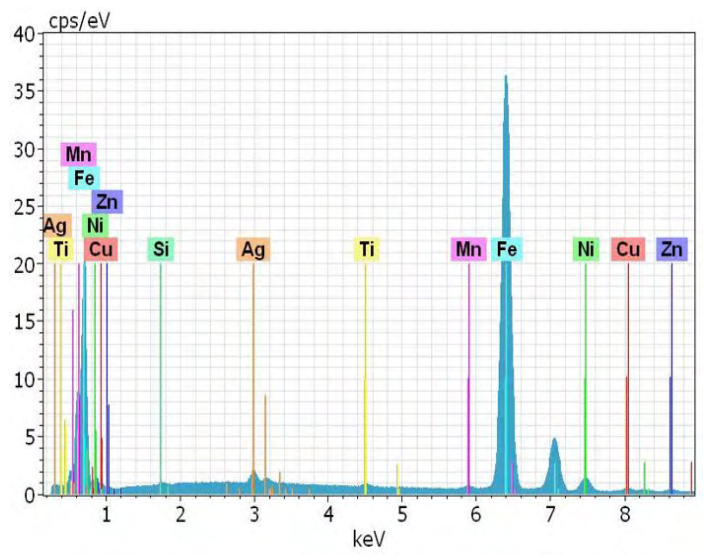

12. ábra. EDX-spektrum a forrasztott mintáról

kérgek, keskeny hőhatásövezetek keménységmérésére használható a mikro-keménységmérés is.

A hegesztett varratok és hőhatásövezetük keménységadatainak Vickers-módszerrel történő meghatározása - az anyagminőség és a technológiai paraméterek ismeretében - többféle információt nyújthat:

- az alapanyag és a varrat keménységkülönbsége egyfajta duktilitásváltozási adatnak is tekinthető, ugyanis az alakváltozó képességet a keménységgel szokás jellemezni, ami szoros öszszefüggésben van az acélok martenzittartalmával. Ezt pedig a karbonegyenérték (C + ötvözők) és adott hőmérséklet-tartományban létrejövő lehűlési sebesség (hűlési idő) befolyásolja;

- a keménységértékeket a varrat hossztengelyére merőleges irányban mérve, illetve ábrázolva, a kapott keménységeloszlás jól mutatja a termikus folyamatok hatásait, az egyes zónákban kialakult hőkezelési effektusokat;

- a keménységértékeket a varrat hossztengelyével párhuzamosan mérve, kimutatható a varratfém tulajdonságegyenletessége;

- a hőmérséklet függvényében mért értékek a mikroszerkezet termikus stabilitására (megeresztésállóságára) utalnak.

Ez utóbbi esetben az adott hőmérsékleti keménységkülönbség vagy az előírt keménységszinten mérhető hőmérséklet-különbség lehet minősítő adat.

A mikroszkópi vizsgálatokhoz készített csiszolatokat használtuk fel a keménységmérésekhez.

A lézerhegesztett minta keménységeloszlás-méréséből kitűnik az a nagy energiasűrűségű eljárásokra jellemző kép, miszerint a legnagyobb értékek a varratban fordulnak elő. A kondenzátor-

\section{Keménység lefutás}

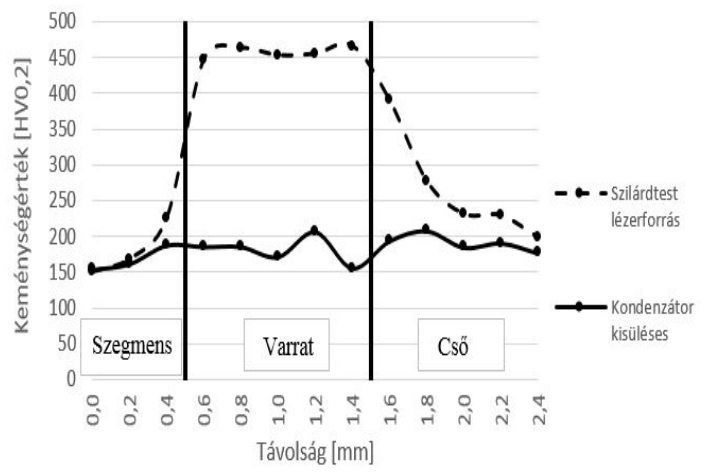

13. ábra. Keménységvizsgálat eredménye

kisülésesen hegesztett minta keménységértékei kb. 50 HV0,2 sávon belül mozognak (13. ábra).

\section{5. Összefoglalás}

Mindhárom mintagyártás esetén ugyanolyan komponenseket használtunk, mint amilyeneket a szériagyártásban. A szegmenseket és csöveket is egy-egy gyártási mennyiségből vettük ki, a különbségek minimalizálása érdekében. A geometriai méréseknél azt tapasztaltuk, hogy a technológiának hatása van a geometriai jellemzőkre, ezt a következő mintagyártásoknál figyelembe kell venni vagy ki kell küszöbölni. A törésteszt eredményei alapján a minták megfelelnek a jelenlegi rajzi előírásoknak, mivel az előírt minimális törésérték feletti értékeket mértünk.

A szériagyártásban alkalmazott vizsgálatok alapján azt mondhatnánk, hogy mindhárom minta megfelel az elvárásoknak. Azonban új kötőtechnológia alkalmazása esetén ezek a vizsgálatok szükséges, de nem elegendő feltételei a minősítésnek.

Az optikai mikroszkópos felvételek megmutatták, hogy a kötésekben lehetnek gázzárványok, néhol mikrorepedések is, ezt a SEM-vizsgálatok is megerősítették. Az elemtérképek kimutatták, hogy nem kell átötvöződéssel számolni a varratban.

Végeredményben megállapíthatjuk: a vizsgált kötési eljárások alkalmasak arra, hogy további mintagyártás során visszaellenőrizzük az eddigi vizsgálati eredményeket és javító intézkedéseket definiáljunk, amennyiben a kötési zóna optimalizálása szükséges. 


\section{Köszönetnyilvánítás}

A szerzők szeretnének köszönetet mondani a Bay Zoltán Alkalmazott Kutatási Közhasznú Nonprofit Kft. kollégáinak a laborvizsgálatok elvégzésében nyújtott segítségükért.

\section{Szakirodalmi hivatkozások}

[1] Kenéz A. Zs.: Gyémántszegmenses fúrókoronák gyártása és tesztelése. Hegesztéstechnika, 29/2. (2018) 63-67.

[2] Kenéz A. Zs., Bagyinszki Gy.: Gyémántszemcsés fúrószegmensek rögzítéstechnológiáinak vizsgálata. In: 29. Nemzetközi Hegesztési Konferencia. Miskolc, Magyarország. 2018. 199-209.

[3] Bagyinszki Gy., Bitay E.: Hegesztéstechnika I. Eljárások és gépesités. Erdélyi Múzeum-Egyesület, Kolozsvár, 2010, 288.
[4] Bagyinszki Gy., Bitay E.: Nagy energiasürüségü eljárások hegeszthetőségi szempontjai. In: XVII. Fiatal Műszakiak Tudományos Ülésszaka. Kolozsvár, Románia, Müszaki Tudományos Füzetek 6. 2012. 13-18.

[5] Harms \& Wende GmbH \& Co. KG, Principle of Capacitor Discharge welding.

https://www.harms-wende.de/en/knowledge/ resistance-welding/cd-welding/ (letöltve: 2018. április 27.).

[6] EN 10305-1: Steel tubes for precision applications - Technical delivery conditions. Part 1: Seamless cold drawn tubes, 2002. november.

[7] EN ISO 3677:2016: Filler metal for soldering and brazing, 2016. szeptember. 